\title{
Bilecik Şehrinin Sosyoekonomik Gelişmişlik Profilinin Mekânsal Analizi 1
}

Öznur AKGISS-ILHAN (https://orcid.org/0000-0001-7224-8353), Department of Geography, Kurşehir Ahi Evran University, Turkey; e-mail: oznrakgis@gmail.com

Erdal KARAKASS (https://orcid.org/0000-0002-7687-9686), Department of Geography, Bilecik Şeyh Edebali University, Turkey; e-mail: erdal.karakas@bilecik.edu.tr

\section{Spatial Analysis of the Socio-Economic Development Profile of Bilecik City, Turkey ${ }^{2}$}

\begin{abstract}
The present study aims to establish the spatial profile of the socio-economic development in Bilecik city, Turkey. The study develops an original scale to measure the socio-economic development and presents a mapping corresponding to the development level associated with the respective regions of Bilecik. The structures related to the measured phenomena are mapped, and the factors affecting the development level are determined. Some of the study's main findings are as follows: (i) Socioeconomic development in the city varies according to regions. (ii) The northern and eastern regions are more developed than the other parts of the city. (iii) The satisfaction with public services and the satisfaction with socio-economic life are the two factors determining the development level. Accordingly, it is possible to say that subjective welfare indicators largely control socio-economic development in the study area.
\end{abstract}

Keywords

JEL Classification Codes : $\quad$ D30, O12.
Socio-economic Development, Socio-economic Development Scale, Bilecik, Turkey.

\section{$\ddot{O} z$}

Çalışmanın konusunu Bilecik şehrinde sosyoekonomik gelişmişliğin mekânsal profili oluşturmaktadır. Çalışma, nicel araştırma tekniklerinden faydalanılarak tasarlanmış, sosyoekonomik gelişmişliğin ölçülmesine yönelik özgün bir ölçek geliştirilmiştir. Çalışma alanında bölgelere göre gelişmişlik düzeyleri belirlenmiş ve haritalanmıştır. Buna ek olarak ölçülen fenomene ilişkin yapılar haritalanmış, gelişmişlikle etkili unsurların neler olduğu tespit edilmiştir. Araştırmanın temel bulguları şu şekildedir: Şehirde sosyoekonomik gelişmişlik bölgelere göre farklılık göstermektedir. Şehrin kuzey ve doğusu diğer bölgelerine göre daha fazla gelişmiştir. Gelişmişlik üzerinde belirleyici iki faktör bulunmaktadır. Bunlar kamusal hizmetlerden memnuniyet ile sosyoekonomik yaşamdan duyulan memnuniyettir. Buna göre çalışma alanında sosyoekonomik gelişmişliğin büyük ölçüde öznel refah göstergeleri tarafından denetlendiğini söylemek mümkündür.

1 Bu çalışma, Öznur Akgiş-İlhan tarafindan hazırlanan ve 2019 yllında Bilecik Şeyh Edebali Üniversitesi, Sosyal Bilimler Enstitüsünde kabul edilen "Bir Mekânın Sosyoekonomik Coğrafi Görünümünün Belirlenmesi: Bilecik Şehri Örneği" başlıklı doktora tezinden uyarlanmıştır.

2 This study was adapted from the "Determination of Socio-economic Landscape of a Space: A Case Study of Bilecik City" which was prepared by Öznur Akgiş-IIlhan and accepted in the Institute of Social Sciences, Bilecik Şeyh Edebali University, in 2019. 
Anahtar Sözcükler
: Sosyoekonomik Gelişmişlik, Sosyoekonomik Gelişmişlik Ölçeği, Bilecik, Türkiye.

\section{Giriş}

Sosyoekonomik gelişmişlik çok boyutlu bir kavramdır. Bu nedenle evrensel bir kabulünden söz etmek mümkün değildir. Ancak ilgili yayın dizin doğrultusunda temelde iki farklı yaklaşımdan söz etmek mümkündür. Bunlardan ilki gelişmişliğin maddi bir süreç başka bir ifade ile ekonomik büyüme olduğunu, ikincisi ise gelişmişliğin bunun ötesinde olduğunu savunanlardır.

Birinci yaklaşım geleneksel görüş olarak adlandırılmaktadır. Buna göre gelişmişlik ya da kalkınma, tarımda çalışan iş gücünün azaltılması buna karşın sanayi sektöründe çalışanların oranının artması şeklindeki iş gücü profilinde gerçekleştirilmesi planlanan yapısal değişimlerle ilişkili bir süreç olarak kabul edilmekteydi (Akgiş \& Karakaş, 2019). $\mathrm{Bu}$ doğrultuda gelişmeyi amaçlayan uygulamalarda iş gücü profili odak noktasını oluşturmaktaydı. Çünkü nüfusun işgücü yapısında yaşanacak değişimle birlikte kişi başına düşen gelirin artacağı ve artan gelirin sosyal refaha katkı sağlayacağı varsayılmaktaydı ${ }^{3}$. Bunun yolu ise gelişmekte olan ülkelerde, batılı uzmanlara anahtar bir rol kazandırmaktı. Bu bağlamda 1950 ve 1960'lı yıllar, azgelişmiş ülkelerde uygulanan batı modernizasyonuna ilişkin politikalarla karakterize edilir. Bu dönem azgelişmiş ülkelerin pek çoğunun ekonomik anlamda gelişme hedeflerine ulaştıkları dönemi temsil etmektedir. Ancak ekonomik gelişme beraberinde sosyal anlamda gelişmeyi getirmemiştir (Todaro \& Smith, 2006; Conceiçao \& Bandura, 2008). Başka bir ifade ile artan gelir, cinsiyet eşitsizliği, gıdaya erişim, anne ve bebek ölüm oranları, okuryazarlık gibi sorunlarla mücadelede etkili olmamıştır. Bu durum modernleşme teorisi ve ilişkili politikaların azgelişmiş ülkelerde gelişmeyi teşvik etmek bir yana bunu engellediği fikrinin giderek daha yaygın kabul görür olmasına neden olmuştur (Potter vd., 2004; Mackinnon \& Cumbers, 2007). Dolasiyla 1970'li yıllardan itibaren gelişmişlik kavramı, yoksulluğun giderilmesi, eşitsizlik ve işsizliğin önlenmesi, temel hizmetlere erişimin sağlanması gibi kavramların tekrar ele alınmasıyla yeniden tanımlanmıştır. Bunlara ek olarak seçim özgürlüğünün sağlanması, öz sayg1, yaşam hakkı gibi ekonomik olmayan göstergelerde gelişmişlik ve kalkınma kavramları içinde yer almaya başlamıştır (Easterlin, 2006; Van Pragg vd., 2003; Peet \& Hartwick, 2009) ki bu anlayış ikinci yaklaşımı savunanları temsil etmektedir. Özellikle Sen'in (1987) refah konusundaki yenilikçi fikirlerinden doğan kapasite yaklaşımı, gelişmişlik anlayışının değişiminde oldukça etkili olmuştur. Özetle günümüzde gelişmişliğin ne olduğu konusunda olmasa da ne olmadığı konusunda evrensel bir kabul vardır. O da gelişmişliğin yalnızca gelir artışı ile ifade edilemeyecek basit bir kavram olmadığıdır.

$\mathrm{Bu}$ çalışma sosyoekonomik gelişmişliğin ölçümüne ve Bilecik şehrinin mekânsal gelişmişlik profilinin oluşturulmasına odaklanır. Çalışmada sosyoekonomik gelişmişlik

\footnotetext{
Bu yaklaşımın sembolik başlangıcı Amerika Birleşik Devletleri başkanı Harry Truman'ın 1949 yılında yaptı̆̆ı konuşmadır. Truman konuşmasında azgelişmiş ülkeleri "Üçüncü Dünya" olarak tanımlamış ve bu alanlarda kalkınmanın sağlanmasının Batı dünyasının bir görevi olduğunu ifade etmişstir.
} 
ekonomik, sosyal ve öznel olmak üzere üç boyutlu bir kavram olarak kabul edilmektedir. $\mathrm{Bu}$ doğrultuda özgün bir sosyoekonomik gelişmişlik ölçüm aracı geliştirilerek çalışma alanının sosyoekonomik gelişmişlik haritasının geliştirilmesi amaçlanmıştır.

\section{2. İlgili Çalışmalar}

Sosyoekonomik gelişmişlik ve kalkınmanın mekânsal analizi eşitsizliklerinin azaltılması, bölgesel sürdürülebilir kalkınmanın sağlanması ve bölgesel planlama açısından önemli bir araştırma konusunu oluşturur (Tian \& Wang, 2019). Sosyoekonomik gelişmişliği konu alan araştırmaların tarihi oldukça eskiye gider. Buna karşın gelişmişliği etkileyen veya üreten ve gelişmişlik farklılıkları tarafından üretilen mekanlar ve toplumsal özellikleri tamamen açıklamak oldukça güçtür. $\mathrm{Bu}$ nedenle sosyoekonomik gelişmişliğe ilişkin çalışmaları güncel konu ve trendler bağlamında ele almak daha doğru olacaktır.

Sosyoekonomik gelişmişliği konu alan araştırmalarda önemli başliklardan biri turizmdir (Akama \& Kieti, 2007). Bunun nedeni kuşkusuz turizmin yerel, bölgesel ve ulusal düzeyde insan refahını artırmaya yönelik politika ve uygulamalara katkı sağlayan bir sektör olduğu gerçeğidir (İlhan vd., 2020; Rogers, 2008). Elbette turizm ve sosyoekonomik gelişmişlik ilişkisini bilimsel literatürde bir yenilik olarak tanımlamak doğru olmaz. Ancak yeni turizm türlerinin doğuşu ve bu faaliyetlerin gelişmişlik ile olan ilişkisine yönelik kanıtlar yeniliktir. Örneğin jeoturizm, gezginlerin doğal ev sahibi toplumların kültürel kimliği ve onları koruma yolları hakkındaki bilgilerini artırmalarına yardımcı olan yeni bir harekettir. Her ne kadar yeni bir turizm türü olarak değerlendirilse de turist sayısını artırarak yerel ekonomik kalkınmada önemli rol oynadığı tespit edilmiştir (Dowling \& Newsome, 2018; Gerner vd., 2009; Farsani vd., 2011). Özel ilgi turizmlerinin de sosyoekonomik gelişmişlik konusunda kitle turizmi kadar olmasa bile olumlu etkilerinden söz etmek mümkündür. Örneğin Ma vd.’nin (2020) “Büyük Amerikan Güneş Tutulması” ve turizm ilişkisini konu aldıkları ilgi çekici araştırmaları bu anlamda dikkate değerdir. Çünkü turistlerin oradaki varlığı ve motivasyonları "o olay", "o yerde olduğu içindir. Bu durum coğrafyanın motivasyon üretmede gücünü açıkça gösterir. "New Age Tourism” (Perneck \& Johnston, 2006) ve gastronomi turizmi de (De Jong \& Varley, 2017) özel ilgi turlarına örnek verilebilir. Turizm olumlu birtakım sosyoekonomik etkilerine rağmen bölgenin ekolojisinin tahrip edilmesi, gürültü kirliliği ve kötü atık yönetimi gibi çeşitli olumsuz çevresel etkilerde yaratmaktadir.

Sosyoekonomik gelişmişliği belirli demografik ya da kültürel gruplar bağlamında ele alan araştırmaların sayısında da artış dikkat çeker. Toplumsal cinsiyet ile ilgili araştırmalar bunlardan biridir (Anderson \& Kohler, 2015). Ahmed vd. (2020) tarafından Bangladeşli kadınların sağlık hizmetlerinden faydalanma durumunu inceledikleri araştırma, Bhuyan vd. (2020)'nin Hindistan'da sosyoekonomik gelişmişlik bağlamında beslenme ve yoksulluğu cinsiyetle ilişkili olarak ele aldıkları çalışma bu anlamda örnek gösterilebilir. Kadınlara ek olarak çocuk ve yaşlıların sosyoekonomik karakteristiklerine ve refahlarına yapılan vuru da giderek artmaktadır (Huebener vd., 2019; Thoma vd., 2020). 
Küresel nüfusun giderek artışı beraberinde çevresel tehditlerin artışını getirmiş bu süreçte giderek artan çevresel problemler sürdürülebilir yaklaşımlara duyulan ihtiyacı şiddetlendirmiştir. Bu anlamda küresel ekonomi, kalkınma ve refahın çevresel göstergeler ile olan ilişkisi giderek daha fazla sorgulanır olmuştur. Bu bağlamda sosyoekonomik gelişmişlik ile çevre etkileşimini konu alan araştırmalarında arttığı görülür. Sosyoekonomik gelişmişlik araştırmalarına konu olan çevresel konulardan bazıları şu şekildedir: hava kalitesi (Shi \& Wu, 2020), toprak erozyonu (Wang vd., 2020), gürültü kirliliği (Tong \& Kang, 2020). Sosyoekonomik gelişmişliğe ilişkin eşitsizlik özellikle kentlerde arazi kullanımından kentsel coğrafi görünüme belirgin farklılıklar oluşturur. Bu durum gelişmişlik araştırmaları ile kentsel planlama arasında dikkat çekici bir yakınsamanın ortaya çıkmasına neden olur. Dolayısıyla kentsel planlama (Fuesini \& Kemp, 2015), kentsel arazi kullanımı (Long vd., 2007; Lambin \& Meyfroidt, 2010; Schmitz vd., 2012; Wu vd., 2013; Cheng vd., 2018) ve sosyoekonomik gelişmişlik ilişkisini konu alan araştırmaların varlığından da söz edilebilir.

Değişen dünyanın bir diğer karakteristiği küresel ekonomiden gündelik yaşama kadar giderek daha görünür hale gelen dijitalleşmedir. Buna bağlı olarak başta bilgi ve iletişim teknolojileri olmak üzere dijital teknolojilerin ekonomik sektörlerde oluşturduğu dönüşüm ve bunun sosyoekonomik gelişmişlik ile olan ilişkisi önemli araştırma konuları olarak dikkat çeker. Gelişmekte olan bir ülkenin sosyoekonomik kalkınmasında bilgi ve iletişim teknolojilerinin (BİT) önemli bir rol oynayabileceğine dair yaygın bir inanç vardır. Çünkü bilgi ve iletişim teknolojileri, GSYİH artışı, istihdam, üretkenlik, yoksulluğun azaltılması, yaşam kalitesi, eğitim ve sağlık hizmetleri gibi ekonomik ve toplumsal faaliyetleri olumlu yönde etkileme potansiyeline sahiptir (Palvia vd., 2018). Bu varsayımdan hareketle BİT'lerinin sosyoekonomik gelişmişle olan ilişkisi giderek daha fazla sorgulanır olmuştur (Alderete, 2017; Roztocki \& Weistroffer, 2018).

Sosyoekonomik gelişmişlik bireysel düzeyde, kişisel gelir, servet, eğitim seviyesi ve meslek gibi faktörlerle ölçülen bir fenomendir. Örgütsel düzeyde, sosyoekonomik gelişme, küresel rekabet gücü, gelir, tüketici talepleri, istihdamda iyileşme ve markalaşma gibi gelişmelerle kendini gösterebilir. Ülke düzeyinde ise sosyoekonomik gelişme, artan ulusal ürün ve refah, gelişmiş siyasi özgürlük, gelişmiş işgücü piyasası ve uluslararası itibar gibi çeşitli göstergelerden faydalanılarak ölçülür. Bu anlamda görüleceği üzere sosyoekonomik gelişmişliğe ilişkin göstergelerin çeşitli ölçekte farklılaşması beraberinde konuya ilişkin araştırmalarında oldukça çeşitli olması sonucunu doğurmaktadır. Bununla birlikte konuya ilişkin araştırmalar değerlendirildiğinde sosyoekonomik gelişmişlik araştırmalarının günümüzde ağırlıklı olarak sürdürülebilirlik ile döngüsel ve dijital ekonomilerle ilişkili olarak mekanla olan etkileşimi bağlamında ele alınan bir araştırma konusu olduğu görülür.

\section{Veri ve Yöntem}

\subsection{Araştırmanın Varsayımları}

Araştırma, Bilecik şehrinde sosyoekonomik gelişmişliğin mekânsal karakteristiklerinin belirlenmesine odaklanır. Bu bağlamda araştırmada şu sorulara yanıt aranmıştır: 
- Bilecik şehrinde sosyoekonomik gelişmişliğin mekânsal profili nasıldır?

- Bilecik şehrinde sosyoekonomik gelişmişliğin mekânsal dă̆ılımını etkileyen faktörler nelerdir?

İfade edilen araştırma soruları bağlamında çalışmanın pozitivist epistemoloji ile uyumlandığı görülmektedir. Çünkü araştırmanın temel kabulü pozitivist epistemolojide olduğu gibi "benim dışımda bir gerçeklik vardır ve bu dış gerçeklik duyularla bilinebilir ve duyular yoluyla elde edilen bu bilgi nesneldir" şeklindeki ontolojik kabuldür. Bu anlamda sosyoekonomik gelişmişlik bir dış gerçeklik olarak kabul edilmektedir. Nicel araştırma yöntem ve araçlarından faydalanılarak incelenen fenomen hakkında genellenebilir, geçerli ve güvenilir bilginin elde edilebileceği varsayılmaktadır. Nicel araştırma yöntemlerinin tercih edilme nedenlerinden bir diğeri araştırma sonucu elde edilecek bulguların doğrudan faydaya dönüştürülebilir olmasıdır. Çünkü yerel ya da bölgesel kalkınmaya katkı sunması hedeflenen araştırmalarda betimsel çalışmalar kimi zaman tek başına yetersiz kalmakta, istatistiksel olarak genellenebilir, geçerli ve güvenilir bilgiye ihtiyaç duyulmaktadır. Elde edilen çıktılar da Bilecik şehrinde hangi alanların sosyoekonomik anlamda dezavantajlı olduğunun belirlenmesini ve gelişmişlik karakteristikleri bağlamında şehrin mekânsal bir çerçevesinin oluşturulmasını sağlayacaktır. Sonuç olarak kaynak dağıtımını daha verimli hale getirebilecek bulgulara ulaşılacaktır.

Özetle araştırma ontolojik olarak sosyoekonomik gelişmişliğin nesnel bir gerçeklik olduğunu varsayar; epistemolojik olarak pozitivizmin nesnelci varsayımı nedeniyle sosyoekonomik gelişmişliğin ne olduğu ve onu etkileyen unsurlar ile araştırma alanında nasıl farklılaştığına; metodolojik anlamda ise nicel araştırma teknikleri kullanılarak sosyoekonomik gelişmişliğin ölçülmesine odaklanır (Şekil 1).

Şekil: 1

Araştırmanın Ontolojik, Epistemolojik ve Metodolojik Varsayımları

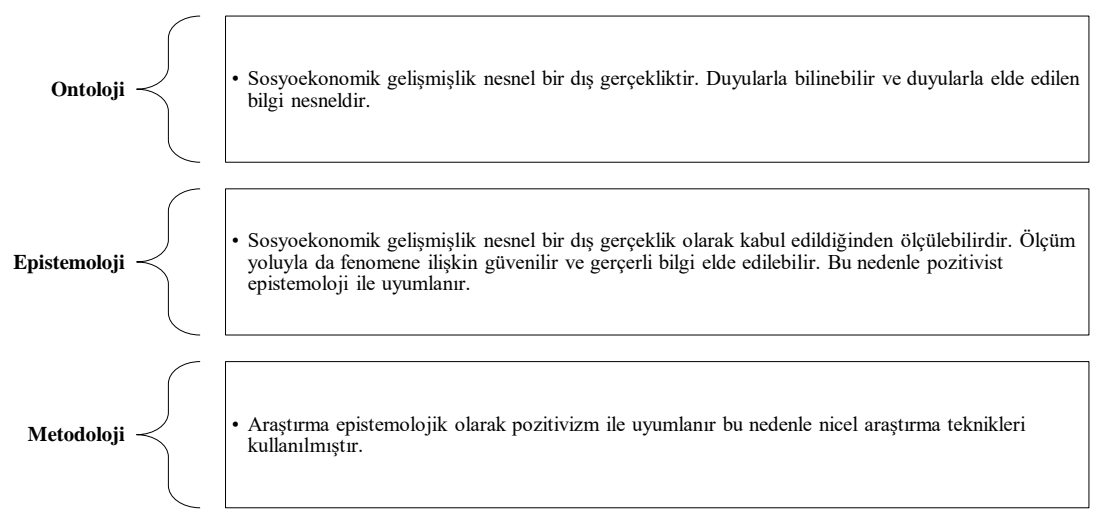




\subsection{Araştırma Evreni ve Örneklem}

Araştırma evrenini Bilecik şehrinde yer alan Bahçelievler, Beşiktaş, Cumhuriyet, Ertuğrulgazi, Gazipaşa, Hürriyet, Orhangazi, Osmangazi, İsmetpaşa, İstasyon, İstiklal, Pelitözü mahalleleri ve bu mahallelerde yaşayan nüfus oluşturmaktadır (Şekil 2).

Bilimsel araştırmalarda doğru bilgi sahibi olmak ve doğru karar vermek esastır. Bu yüzden doğru bilgilere ulaşmak ve elde edilen bilgileri genelleştirmek ihtiyacı vardır (Arıkan, 1994). Bu bağlamda örneklemin alınmasında, alındığı evreni temsil etmesi büyük önem taşımaktadır. Dolayısıyla bu aşamada hangi büyüklükteki bir örneklemin evreni temsil edebileceği sorusu ortaya çıkmaktadır. Araştırmanın gerçekleştirildiği Bilecik şehrinde hedef kitledeki birey sayısı TÜIK Adrese Dayalı Nüfus Kayıt Sistemi 2018 yılı sonuçlarına göre 67.891'dir. \%95 güven düzeyi ve $\% 5$ hata payı dikkate alındığında 382 kişiye ölçek uygulanması yeterlidir. Buna karşın sosyoekonomik gelişmişliğin mekânsal dağıllış özelliklerinin belirlenmesinde kullanılacak olan mekânsal kümelenme analizinin uygulanabilmesi için en az 30 mekânsal birime ihtiyaç duyulmaktadır. Çalışma alanında 12 mahalle bulunması mekânsal istatistiksel analizin uygulanmasında bu anlamda kısıtlılıktır. Bu nedenle çalışma alanını oluşturan 12 mahalle, cadde ve konut yoğunluğu dikkate alınarak 35 mekânsal alt birime ayrılmıştır (Şekil 2). Her bir mekânsal birim içinde de en az 30 örneklem bulunması gerektiği düşünüldüğünde 659 değil 1110 kişiye ölçek uygulaması gerektiği tespit edilmiştir. Bu doğrultuda 2019 yılı Mayıs ve Haziran aylarında 1154 kişiye ölçek uygulanmıştır. Uygulanan ölçeklerden 51 değerlendirmeye alınmamıştır. Sosyoekonomik gelişmişliğin boyutlarının belirlenmesinde faktör analizinden, gelişmişliği etkileyen faktörlerin belirlenmesinde ise basit doğrusal regresyon analizinden faydalanılmıştır.

\subsection{Mekânsal Analiz Araçları}

Coğrafi bakış açısıyla yapılacak kalkınma araştırmaları azgelişmişlik durumunun nedenleri ve bu sorunla mücadelede alınacak önlemler konusunda büyük önem taşır (Henninger \& Snel, 2002; Hyman vd., 2005). Özellikle gelişmişliği konu alan haritalar, ilişkili sorunların nerelerde yoğunlaştığını ifade ettiğinden, kaynak dağıtımının verimli hale getirilmesinde oldukça etkilidir (Fujii, 2008). Bu bağlamda araştırma sahasında sosyoekonomik gelişmişlik konusundaki dezavantajlı alanların belirlenmesine yönelik Bilecik şehrinin gelişmişlik haritası elde edilmiştir. Elde edilen bu harita şehirdeki azgelişmiş grupların yoğunlaştı̆̆ yerleri göstermesi açısından önemlidir. Sosyoekonomik gelişmişlik durumunun mekânsal oto-korelâsyonu Global G istatistiğinden faydalanılarak incelenmiştir. Getis-Ord's Gi* istatistiği incelemeye alınan değişkenlerin kümelenme eğilimlerinin bulunup bulunmadığını, kümelenme varsa hangi alanlarda olduğunun belirlenmesinde kullanılır. Örneklemdeki birimler için bu istatistikten faydalanılarak sıcak ve soğuk noktalar belirlenebilir. İfade edilen sıcak noktalar, yüksek değişken değerine sahip noktaların oluşturduğu kümeleri, soğuk noktalar ise düşük değişken değerine sahip noktaların oluşturduğu kümeleri ifade eder (Getis \& Ord, 1992; Çubukçu, 2015). Moran's I endeksi de Getis-Ord endeksine benzer şekilde mekânsal kümelenmelerin belirlenmesinde kullanılır. Pozitif Moran'ın I değeri, incelenen konumun komşuları ile benzer şekilde yüksek 
veya düşük değerlere sahip olduğunu, dolayısıyla mekânsal kümelerin olduğunu gösterir. Negatif Moran'ın I değeri, incelenen konumun mekânsal açıdan aykırı bir değere sahip olduğu anlamına gelir. Mekânsal aykırı değerler, çevrelerindeki konumların değerlerinden açıkça farklı olan değerlerdir. Endeks değerinin " 0 " olması ise değerlerin mekânsal dağılımının rastgele olduğunu gösterir (Zhang vd., 2008).

\section{Şekil: 2 \\ Araştırma Alanının Büyük Sokak ve Caddeler Dikkate Alınarak Belirlenmiş 35 Bölgesi}

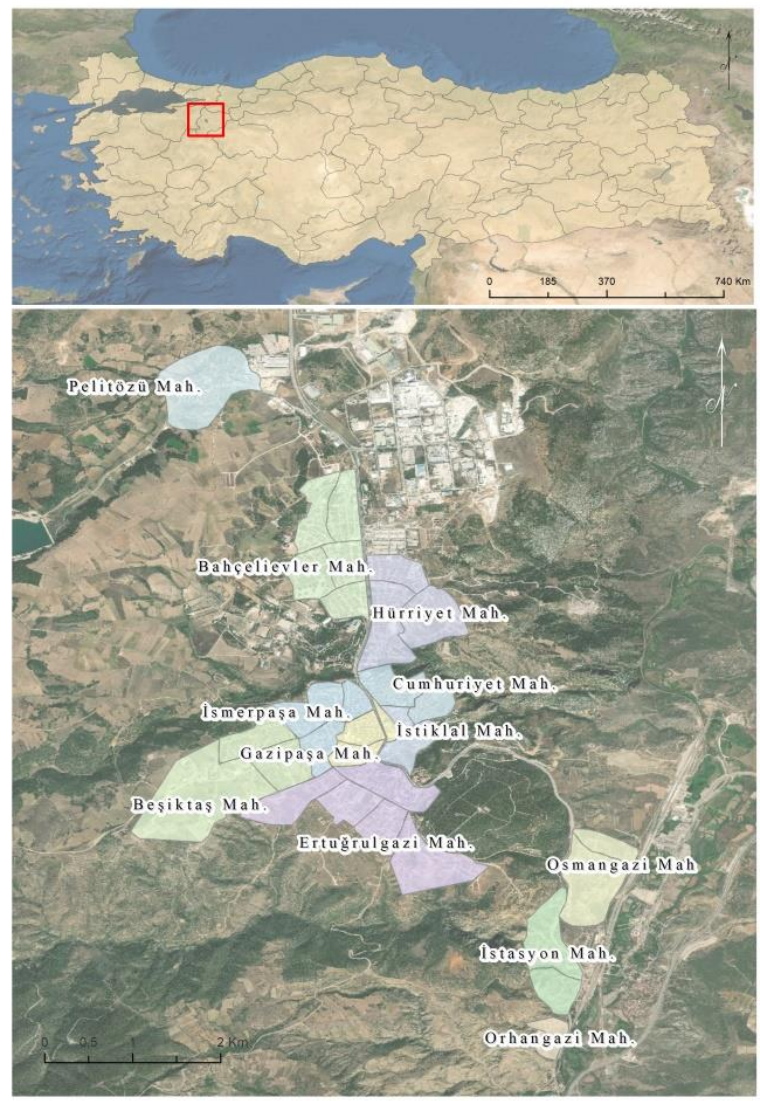

\subsection{Sosyoekonomik Gelişmişlik Endeksinin Geliştirilmesi}

“Benim dışımda bir dış gerçeklik vardır” kabulünden hareketle günlük yaşamda insanlar çevresindeki diğer canlı ya da cansız varlıkları duyuları ile algılayarak onları bazı değerler atayabilir. Bu bağlamda tarihteki ilk ölçme araçları olarak ayak, karış, adım, kulaç vb. gibi unsurlar örnek gösterilebilir. Ancak ölçme işlemi belirli kural ve standartlar çerçevesinde yapılmazsa değerler kişiden kişiye farklılık gösterebileceğinden bilimsel 
anlamda geçerli sonuçlara ulaşılamaz (Karakoç \& Dönmez, 2014). Bu nedenle ölçülmek istenilen konu hakkındaki özelliklerin sınıf, sıra, miktar veya derecelerinin belirlenmesinde belirli araçlar kullanılmaktadır. Bunlara ölçek ismi verilmekte olup nicel araştırma tekniklerinden biri olarak kabul görmektedir.

Geçerli ve güvenilir bir ölçme aracı hazırlanırken izlenilmesi gereken bazı aşamalar bulunmaktadır. $\mathrm{Bu}$ araştırmada kullanılacak sosyoekonomik gelişmişlik ölçeğinin geliştirilmesine yönelik öncelikle ilgili yayın dizini incelenerek giriş bölümünde ifade edilen sosyoekonomik gelişmişlik kavramsallaştırması doğrultusunda fenomenin yapısal özellikleri diğer bir ifade ile alt boyutları belirlenmiştir. Bunlar sosyal, ekonomik ve öznel gelişmişlik olmak üzere üç boyuttur. Daha sonra alt boyutlara ilişkin soru havuzu oluşturulmuştur. Ölçüm formatı olarak sıralama tercih edilmiştir. Seçenekler beş tane olup artan sıralı puana göre hazırlanmıştır ${ }^{4}$. Bu işlemler sonucu denemelik ölçme aracı elde edilmiştir. Son olarak soru ve madde seti gözden geçirilmiş, uzman görüşü alınmış, ön elemeden geçirilmiş ve pilot uygulama gerçekleştirilmiştir.

\subsection{Sosyoekonomik Gelişmişlik Ölçeğine İlişkin Geçerlik ve Güvenirlik Analizi Sonuçları}

Öncelikle güvenirlik ve madde analizi uygulanarak madde, ölçek belirtici istatistikleri, veri yapısına uygun olarak güvenirlik katsayısı (Cronbach Alfa) ve soru silinirse oluşacak güvenirlik katsayısı (If Item Deleted Cronbach Alfa) istatistikleri hesaplanmıştır.

Cronbach Alfa katsayısı sürekli, aralıklı ya da ardışık dört ya da 5 seçenekli cevaplar içeren $\mathrm{k}$ maddenin yer aldığı bir ölçeğin sorgulandığı fenomeni ölçmedeki gücünü, yeterliliğini ve güvenirliğini ölçen genel güvenirlik katsayısıdır. Bu katsayı, ölçekte yer alan maddelerin türdeş bir yapıyı sorgulamak ya da açıklamak üzere bir bütün oluşturup oluşturmadıklarını, ölçeğin genel güvenirliğini sorgulamaktadır (Özdamar, 2016). Ölçeğin güvenirlik düzeyi 0,754 olarak hesaplanmıştır. Özdamar (2016) tarafından $0.50 \leq \alpha<0.60$ durumunda ölçeğin yüksek güvenirlik düzeyine sahip olduğu bu anlamda ölçeğin fenomen ile il ilgili toplum taramalarında ve bilimsel yargıların oluşturulmasında güvenle kullanılabileceği ifade edilmektedir.

Toplanabilirliğe ilişkin Tukey testi sonuçlarına göre maddeler birbirinden önemli düzeyde farklı olduğu belirlenmiştir. Bu sonuç ölçekteki maddelerin en az iki farklı boyutu açıklayacak bir yapıda olduğunu gösterir. Nonadditivity (Toplanabilirlik) olasılığı 0,384'dür. Buna göre ölçekte maddeler toplanabilir özelliktedir. Ölçek değerlendirilmesinde bir diğer aşama açıklayıcı faktör analizi yardımıyla ölçek maddelerinin yeniden değerlendirmeye alınmasıdır. $\mathrm{Bu}$ analiz ile ölçek maddelerinin kaç faktöre ayrılacağına

4 Tutum belirlemeye yönelik sorularda kullanılan "kararsızım” seçeneği, belirsizliği, çekinceyi, yanlılı̆̆ yansitan bir cevap olarak kabul görür. Bu nedenle verilerde olması gereken rastgelelik, bağımsızlı, yansızlık ve normal dağıllm gösterme varsayımlarının yerine getirilememesine neden olmaktadır. Bununla birlikte daha önce ifade edilmiş olan toplanabilirlik özelliğini de bozmaktadır. Bu nedenle tutuma yönelik sorularda "kararsızım" seçeneği kullanılmamıştır. 
ilişkin ön bilgiler elde edilir. Bunun için Kaiser-Mayers-Olkin Örnek Yeterlik Ölçüsü istatistiğinin 0,50'nin üzerinde (KMO $\geq 0.50)$ olması gerekmektedir (Field, 2000; Özdamar, 2016). Buna göre geliştirilen ölçekte KMO testi gereklilikleri sağlanmıştır.

Bartlett küresellik testi ile maddelere verilen cevapların birbirinden bağımsız ya da ilişkili olup olmadığı test edilmektedir. Küresellik testi önemli ise $(p \leq 0.05)$ maddelerin tümünün ya da belirli bir bölümünün birbiri ile önemli korelasyon gösterdiği ve ölçekte en azından bir faktör yapısının bulunduğu anlamı çıkarılır ve ölçeğin fenomeni ölçmede spesifik bir ölçme aracı olduğu görüşüne varılır. Eğer küresellik testi önemsiz ise (p>0.05) maddelerin birbirinden bağımsız olduğu ve ölçeğin bir anket yapısında olduğuna karar verilir. Elde edilen sonuçlara göre küresellik testinin önemli olduğu belirlenmiştir. Sonuç olarak güvenirlik düzeyi yüksek bir sosyoekonomik gelişmişlik ölçeği elde edilmiştir.

Sonraki aşama hangi bileşen ya da bileşenlerin sosyoekonomik gelişmişlik göstergesi olarak dikkate alınacağı sorusudur. Konu hakkındaki yayın dizini incelediğinde sosyoekonomik gelişmişlik ölçeği geliştirildikten sonra birinci temel bileşen değeri dikkate alınarak incelenen il ya da ilçenin sosyoekonomik gelişmişlik seviyesinin belirlendiği tespit edilmiştir (Orta Karadeniz Kalkınma Ajansı, 2014; Ahiler Kalkınma Ajansı, 2013; Doğu Anadolu Kalkınma Ajansı, 2013; Dinçer ve Özaslan, 2004). Başka bir ifade ile her mekânsal birim için birinci temel bileşen değeri dikkate alınarak gelişmişlik değeri elde edilmiştir.

\subsection{Katılımcıların Sosyo-Demografik Profili}

Katılımcıların 615'ini (\%56) erkekler, 488'ini (\%44) kadınlar oluşturmaktadır. Katılımcıların ortalama yaşı 40,37 olup en düşük yaş 20, en büyük yaş ise 90'dır. Mesleklerine göre dağılıma bakıldığında katılımcılar içinde en büyük grubu ev hanımları (\%26) oluşturmaktadır. Ev hanımlarından sonra ise işçiler (\%18) ve emekliler (\%14) gelmektedir. Bu gruplar ise sirasıyla öğrenciler (\%10), esnaflar (\%7), diğer (\%6), öğretim görevlileri ve öğretmenler (\%4), şoförler (\%4), işsizler (\%3), memurlar (\%3), güvenlik personelleri (\%2) ve sağlık personelleri (\%2) izlemektedir.

Katılımcıların eğitim seviyeleri değerlendirildiğinde en büyük grubu ilköğretim mezunu olanların oluşturduğu görülmektedir. $\mathrm{Bu}$ grup katılımcıların \%37'sini oluşturmaktadır. İkinci sırada lise mezunları yer alır. Lise mezunları katılımcıların \%29'unu oluşturmaktadır. Üçüncü sırada ise yüksekokul veya fakülte mezunu olanlar (\%27) gelmektedir. En küçük gruplar ise okuryazar olmayanlar ile lisansüstü eğitim mezunlarıdır. Okuryazar olmayan ve lisansüstü mezunları katılımcıların \%4’ünü oluşturmaktadır.

Katılımcıların \%16'sının hane halkı geliri asgari ücretin altındadır. Asgari ücretle çalışanlar ise katılımcıların \%20'sine karşılık gelmektedir. Aylık hane halkı geliri asgari ücret ile $2.500 \mathrm{TL}$ arasında değişenlerin oranı \%23'tür. Gelir grupları içinde en büyüğü 2.500-5.000 TL aralığıdır. Bu aralıkta gelire sahip olanların oranı \%32'dir. Gelirinin 5.000 TL üzerinde olduğunu belirtenler ise katılımcıların \%9'una karşılık gelmektedir. 


\section{Bulgular}

\subsection{Bölgelerin Sosyoekonomik Gelişmişlik Düzeyleri}

Bölgelerin sosyoekonomik gelişmişlik düzeylerinin hesaplanmasında birinci temel bileşen değeri dikkate alınarak her bir bölge için gelişmişlik değeri elde edilmiştir. Düşük değerler azgelişmişliği, yüksek değerler ise gelişmişliği ifade etmektedir (Şekil 3).

Şehrin sosyoekonomik anlamda en gelişmiş bölgesi Bahçelievler mahallesine bağlı 113 kodlu bölgedir. Gelişmişlik endeksi değeri en yüksek bölgelere de bakıldığında Bahçelievler mahallesinde yer alan bölgelerin dikkat çekici olduğu görülür ki en gelişmiş on bölgeden beşi Bahçelievler mahallesinde yer almaktadır. En gelişmiş ikinci bölge İsmetpaşa mahallesinin kuzeyinde yer alan 143 numaralı bölge, en gelişmiş üçüncü bölge ise Hürriyet mahallesinin en güneyinde yer alan 124 numaralı bölgedir (Şekil 3).

\section{Şekil: 3}

\section{Sosyoekonomik Gelişmişliğin Dağılışı ve Mekânsal Kümelenme Analizi Sonuçları}

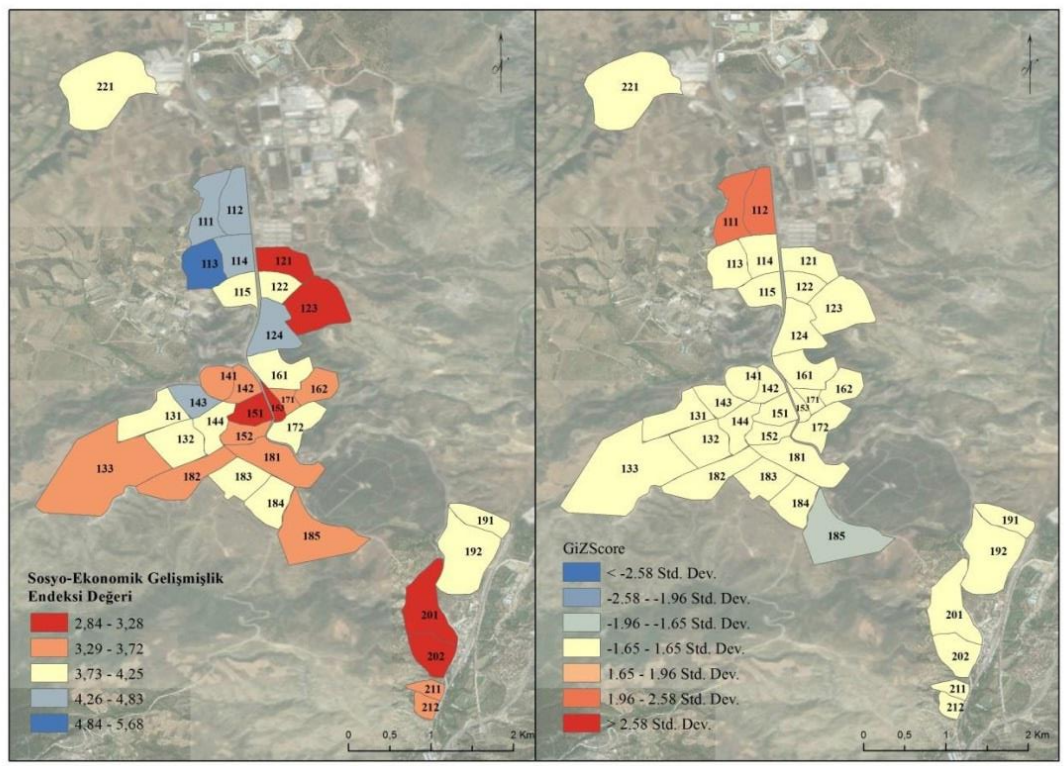

Sosyoekonomik gelişmişliğin en düşük olduğu bölge ise Hürriyet mahallesinin doğusunda yer alan 123 numaralı bölgedir. Onu sırasıyla Gazipaşa mahallesinde yer alan aynı zamanda şehrin Merkezi İş Alanında (MİA) yer alan 151 numaralı bölge ve İstasyon mahallesinin kuzeyinde kalan 201 numaralı bölge izlemektedir. Aynı mahalle içinde yer almasına rağmen sosyoekonomik gelişmişlik anlamında belirgin farklılık gösteren mahallelerin bulunması örneklem gruplarının mahallelere göre değil de daha detaylı bir şekilde ele alınması kararının doğruluğunu ifade etme açısından önemlidir. 
Sosyoekonomik gelişmişliğin mekânsal kümelenme gösterip göstermeme durumu araştırmada yanıt aranan sorulardan biridir. Mekânsal kümelenmeye analizde iki farklı endeksten faydalanılmıştır. Getis-Ord General G endeksi sonuçları mekânsal kümelenmenin olmadığını gösterir. (Şekil 3) Moran's I endeksine göre sosyoekonomik gelişmiş mekânsal kümelenme göstermemektedir. Kümelenmenin varlığına dair elde edilen bulgu ise istatistiksel olarak anlamlı değildir (Tablo 1).

Tablo: 1

Mekânsal Kümelenme Analizi Sonuçları

\begin{tabular}{|c|c|c|}
\hline Moran's Index & 0,00 & General G \\
\hline z-score & 1,10 & 0,20 \\
\hline p-value & 0,26 & z-score \\
\hline
\end{tabular}

\subsection{Faktör Analizine İliş̧kin Bulgular ve Faktörlerin Mekânsal Dağılışı}

Faktör analizi sonuçlarına göre değerlendirmeye alınan değişkenlerin 6 faktör altında toplandığ 1 görülmektedir (Tablo 2). Birinci faktörde yer alan maddelerin tamamı kamusal hizmetlerden duyulan memnuniyete ilişkindir. Bu nedenle bu faktör "kamusal hizmetlerden duyulan memnuniyet" olarak adlandırılmıştır. Kamusal hizmetlerden duyulan memnuniyet faktörünün öz değeri 2,736 olup bu faktörün toplam varyansın \%13'ünü açıkladığ görülmektedir.

Tablo: 2

Sosyoekonomik Gelişmişlik Ölçeğine İlişkin Faktör Analizi Sonuçları

\begin{tabular}{|c|c|c|c|c|c|c|}
\hline Değişkenler/Faktörler & F1 & $\mathrm{F} 2$ & F3 & F4 & F5 & F6 \\
\hline F1. KAMUSAL HIZZMLETLERDEN DUYULAN MEMNUNIYET & & & & & & \\
\hline Ulaşım Hizmetlerinden Duyulan Memnuniyet & ,682 & & & & & \\
\hline Yeșil Alan Miktarından Duyulan Memnuniyet & ,666 & & & & & \\
\hline Eğitim Hizmetlerinden Duyulan Memnuniyet &, 593 & & & & & \\
\hline Asayiș Hizmetlerinden Duyulan Memnuniyet &, 569 & & & & & \\
\hline Yaşanılan Yerde Kendini Güvende Hissetme &, 564 & & & & & \\
\hline Faktör Tarafindan Açıklanan Toplam Varyans & \multicolumn{6}{|c|}{$\% 13$} \\
\hline \multicolumn{7}{|l|}{ F2. SOSYOEKONOMIKK YAŞAMDAN DUYULAN MEMNUNIYYT } \\
\hline Kişisel Sağlıktan Duyulan Memnuniyet & & ,696 & & & & \\
\hline Kişisel Eğitimden Duyulan Memnuniyet & & ,683 & & & & \\
\hline Aylık Hanehalkı Gelirinden Duyulan Memnuniyet & &, 553 & & & & \\
\hline Genel Mutluluk Düzeyi & &, 548 & & & & \\
\hline Seyahat S1klığ1 & &, 528 & & & & \\
\hline Faktör Tarafindan Açılanan Toplam Varyans & \multicolumn{6}{|c|}{$\% 12$} \\
\hline \multicolumn{7}{|l|}{ F3. HANE EKONOMISI } \\
\hline Sahip Olunan Toplam Araç Sayısı & & &, 721 & & & \\
\hline Borç Miktarı & & &, 639 & & & \\
\hline Hanehalk1 Geliri & & &,- 520 & & & \\
\hline Faktör Tarafindan Açıklanan Toplam Varyans & \multicolumn{6}{|c|}{$\% 7$} \\
\hline \multicolumn{7}{|l|}{ F4. SOSYOEKONOMIKK SERMAYE } \\
\hline Tarımsal Arazi Sahipliği & & & & ,716 & & \\
\hline Arsa Sahipliği & & & &, 599 & & \\
\hline Sosyal Ağ (Komşu/Arkadaş) & & & &, 560 & & \\
\hline Faktör Tarafindan Açılanan Toplam Varyans & \multicolumn{6}{|c|}{$\% 7$} \\
\hline \multicolumn{7}{|l|}{ F5. TEHLIKKELİ MADDE KULLANIMI } \\
\hline Alkol Kullanımı & & & & &, 818 & \\
\hline Sigara Kullanımı & & & & & 690 & \\
\hline Faktör Tarafindan Açıklanan Toplam Varyans & \multicolumn{6}{|c|}{$\% 7$} \\
\hline F6. HANE HALKI BÜYÜKLÜĞÜ & & & & & & \\
\hline Hanehalk1 Büyüklüğü & & & & & & ,796 \\
\hline Hanedeki Toplam Çocuk Sayısı & & & & & &, 760 \\
\hline Faktör Tarafindan Açıklanan Toplam Varyans & \multicolumn{6}{|c|}{$\% 6$} \\
\hline Açıklanan Toplam Varyans & \multicolumn{6}{|c|}{$\% 52$} \\
\hline
\end{tabular}


İkinci faktörde yer alan maddelerin tamamı kişisel sosyoekonomik yaşam ve özelliklerden duyulan memnuniyete ilişkindir. Bu nedenle bu faktör "sosyoekonomik yaşamdan duyulan memnuniyet” olarak adlandırılmıştır. Bu faktörün öz değeri 2,413 olup toplam varyansın \%12'sini açıklamaktadır.

Üçüncü faktörde yer alan maddeler hane ekonomisine ilişkindir. Bu nedenle bu faktör “hane ekonomisi” olarak adlandırılmıştır. Bu faktöre ilişkin öz değer 1,569'dur. Toplam varyansın \%7'sini bu faktör ile açılamak mümkündür.

Dördüncü faktör, üçüncü faktöre benzerdir. Büyük ölçüde hane ekonomisi ile ilişkili olup buna ek olarak sosyal ağ varlığı ve büyüklüğünü de içermektedir. Üçüncü maddeden farkı borçluluk gibi “yokluğu” değil yalnızca "sahipliği” içermesidir. Bu nedenle bu faktör "sosyoekonomik sermaye” olarak adlandırılmıştır. Bu faktörün öz değeri 1,438 olup toplam varyansın \%7'sini açıklamaktadır.

Beşinci faktör iki maddeden oluşmaktadır. Birisi alkol diğeri ise sigara tüketimini içermektedir. Her iki maddede tehlikeli maddeler grubunda yer aldığından bu faktör "tehlikeli madde kullanımı" olarak adlandırılmıştır. Bu faktöre ilişkin öz değer 1,437 olup faktör toplam varyansın \%7'sini açıklamaktadır.

Son faktör olan altıncı faktör de iki maddeden oluşmaktadır. Maddelerin ikisi de hane halk1 büyüklüğüne ilişkin olduğundan bu faktör "hane halkt büyüklüğ̈̈̈" olarak adlandırılmıştır. Altıncı faktörün öz değeri 1,354 olup bu faktör toplam varyansın \%6'sını açıklamaktadır.

Sosyoekonomik gelişmişlik ile ilişkili alt boyutların mekânsal deseninin belirlenmesine yönelik faktör haritaları üretilmiştir. Yüncü vd. (2018) tarafindan kullanılan haritalama tekniği ele alınan fenomene dair detaylı çıkarımlar yapmayı ve mekânsal ilişkilerin görünür hale gelmesini mümkün kılmaktadır. Faktör analizi bulgularına göre çalışmada elde edilen birinci faktör kamusal hizmetlerden memnuniyettir. Bu faktör eğitim, ulaşım yeşil alan ve asayiş hizmetlerinden memnuniyet oranı ile ikamet edilen bölgede kendini güvende hissetme durumunu içermektedir. Kamusal hizmetlerden duyulan memnuniyetin dağılışına bakıldığında şehrin en gelişmiş mahallesi olan Bahçelievler'e bağlı bölgelerin en yüksek değerleri aldığ 1 görülmektedir. Şehrin azgelişmiş bölgelerinde ise memnuniyet oranları düşüktür (Şekil 4). 


\section{Şekil: 4 \\ Kamusal Hizmetlerden Duyulan Memnuniyet (1: Düşük Memnuniyet, 5: Yüksek Memnuniyet)}

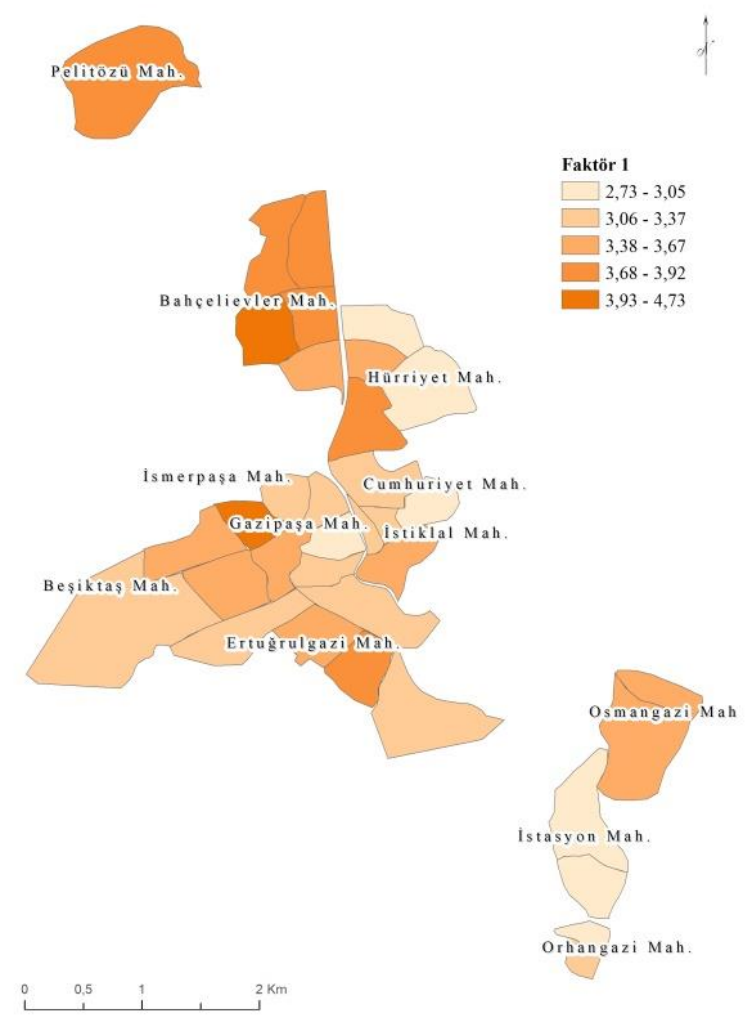

İkinci faktör sosyoekonomik yaşamdan duyulan memnuniyettir. Genel mutluluk düzeyi, kişisel sağlık ve eğitimden memnuniyet, aylık hane halkı gelirinden memnuniyet ve son üç yılda gerçekleştirilen seyahat sayısı yer almaktadır. Sosyoekonomik yaşamdan duyulan memnuniyetin dağılışına bakıldığında bir önceki faktöre benzer şekilde Bahçelievler mahallesine bağlı bölgelerde yüksek olduğu görülür. Ancak bu faktörün dağılışını doğrudan gelişmişlik ile ilişkilendirmek mümkün görünmemektedir. Çünkü Merkezi İş Alanı ve yakın çevresinde yer alan azgelişmiş bölgeler ile Ertuğrulgazi mahallesinin güneyindeki az ve orta düzey gelişmiş bölgelerde de sosyoekonomik yaşamdan duyulan memnuniyetin yüksek olduğu görülmektedir (Şekil 5). 
Şekil: 5

Sosyoekonomik Yaşamdan Duyulan Memnuniyet (1: Düşük Memnuniyet, 5: Yüksek Memnuniyet)

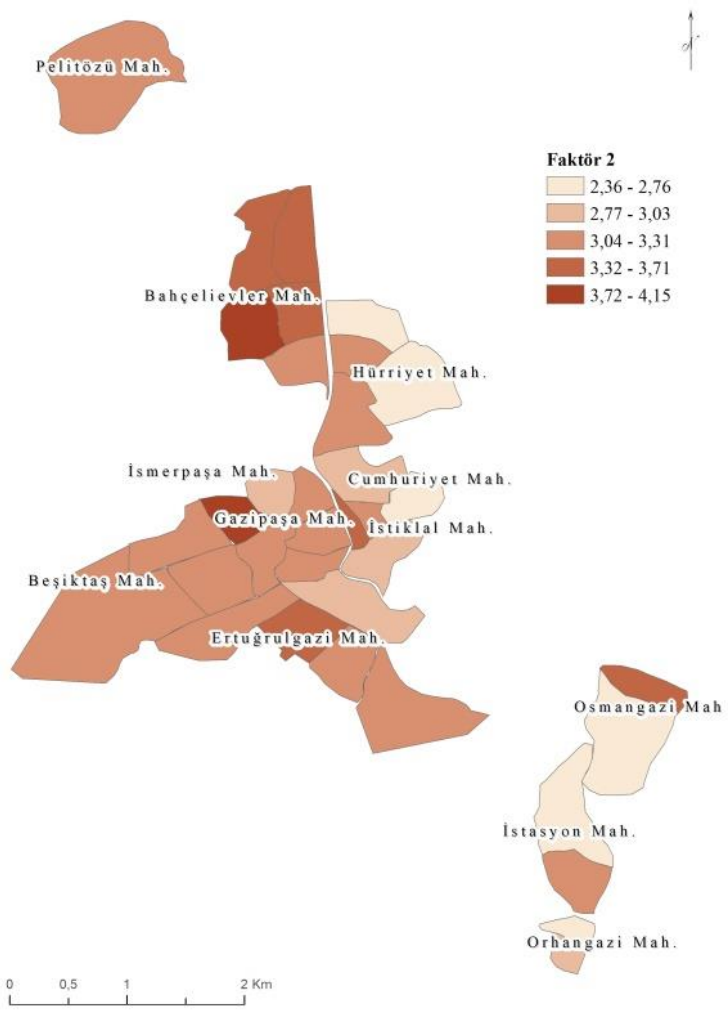

Üçüncü faktör hane ekonomisidir. Hane ekonomisi içinde sahip olunan toplam araç sayısı, herhangi bir kurum ya da kişiye olan borç ile aylık gelir değişkeni yer almaktadır. Hane ekonomisine ilişkin karakteristiklerin dağılışına bakıldığında ekonomik anlamda gelişmişliğin belirgin bir mekânsal deseni olmadığ 1 dikkat çeker. Başka bir ifade ile ekonomik gelişmişlik rastgele dağılış göstermektedir. Şehre bağlı mahallelerin neredeyse tamamında ekonomik anlamda hem azgelişmiş hem de gelişmiş hanelerin yoğunlaştı̆̆ bölgelerden söz etmek mümkündür (Şekil 6). 
Şekil: 6

Hane Ekonomisi (1: Düşük Ekonomik Gelişmişlik, 5: Yüksek Ekonomik Gelişmişlik)

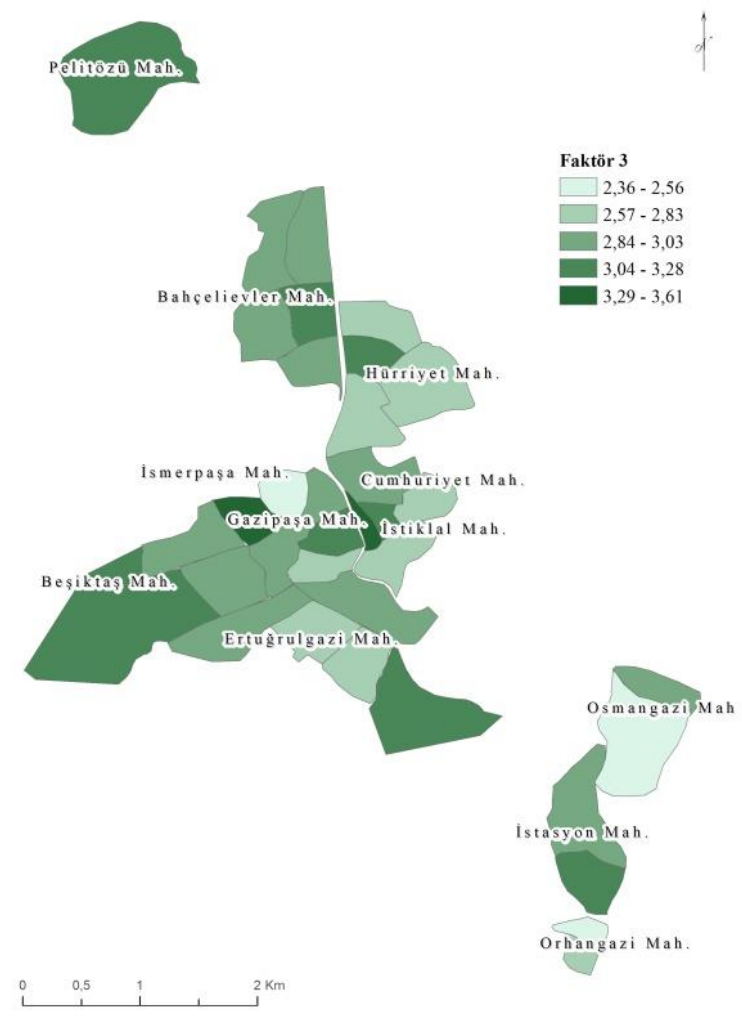

Bir sonraki faktör sosyoekonomik sermayedir. Bu faktör içinde tarımsal arazi ve arsa sahipliği ile miktarı ve ihtiyaç duyulduğunda yardım talep edilebilecek komşu sayısı değişkenleri yer almaktadır. Sosyoekonomik sermayenin dağılışına bakıldığında belirgin mekânsal farklılıktan söz etmek mümkündür. Sermayenin yüksek olduğu alanlar Bahçelievler, Ertuğrulgazi ve Beşiktaş mahalleleri yer almaktadır. En düşük olduğu alanlar ise Hürriyet mahallesi, Merkezi İş Alanı ve yakın çevresindeki bölgeler ile şehrin en güneyinde yer alan Orhangazi mahallesidir (Şekil 7). 


\section{Sekil: 7}

Sosyoekonomik Sermaye (1: Düşük Sermaye, 5: Yüksek Sermaye)

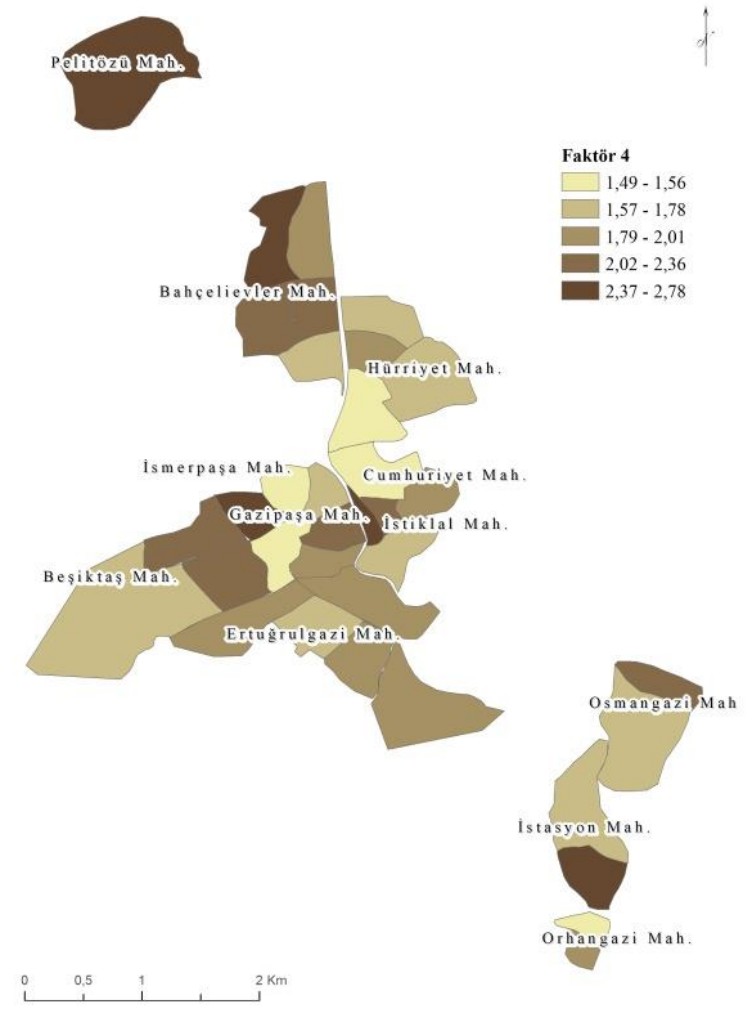

Beşinci faktör tehlikeli madde kullanımıdır. Bu faktör içinde alkol ve sigara kullanımı değişkenleri yer almaktadır. Her iki maddenin de kullanımının en fazla olduğu mahalle İstasyon, en fazla olduğu bölge bu mahallenin güneyinde yer alan 202 numaralı bölgedir. Kullanımın fazla olduğu bir diğer mahalle ise Hürriyet mahallesidir. Tehlikeli madde kullanımının en düşük olduğu bölgeler ise Osmangazi mahallesine bağlı 192 numaralı bölge ile Beşiktaş mahallesine bağlı 133 numaralı bölgedir (Şekil 8). 


\section{Şekil: 8}

\section{Tehlikeli Madde Kullanımı (1: Düşük Kullanım, 5: Yüksek Kullanım)}

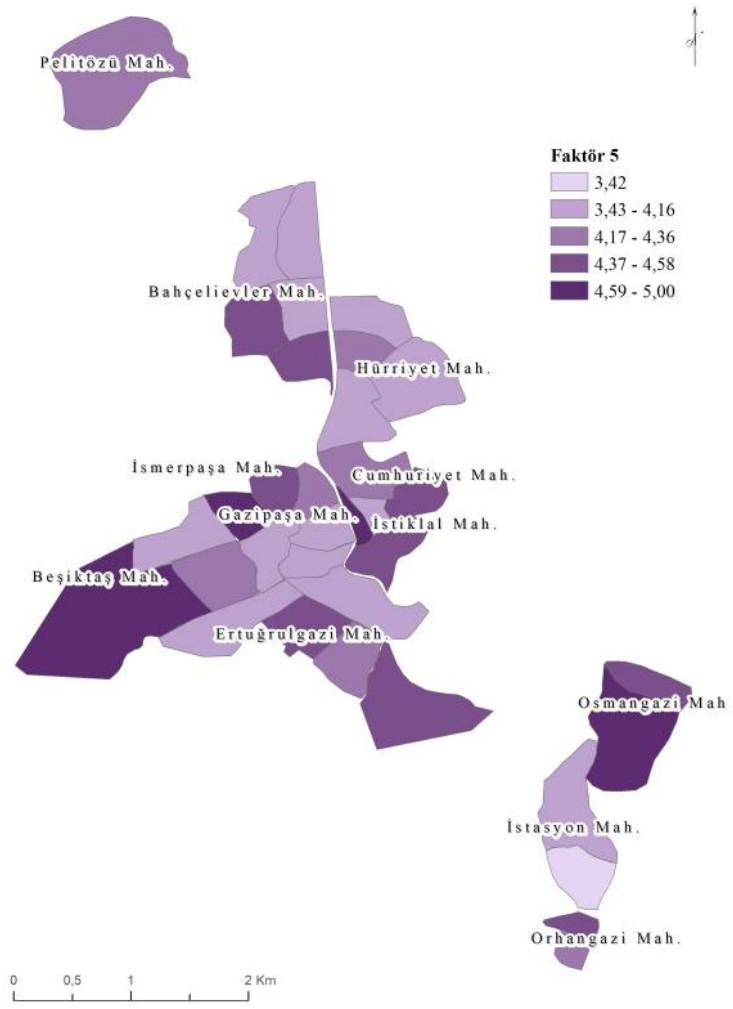

Son faktör hane halkı büyüklügüüur. Faktör, toplam hane halkı büyüklüğü ve hanedeki toplam çocuk sayısından oluşmaktadır. Hane halkı büyüklüğünün en fazla olduğu bölgeler Hürriyet mahallesinin güneyinde yer alan mahalleler ile benzer şekilde Ertuğrulgazi mahallesinin güneyinde yer alan bölgelerdir (Şekil 9). 


\section{Şekil: 9}

Hanehalkı Büyüklüğü (1: Büyük Hane, 5: Küçük Hane)

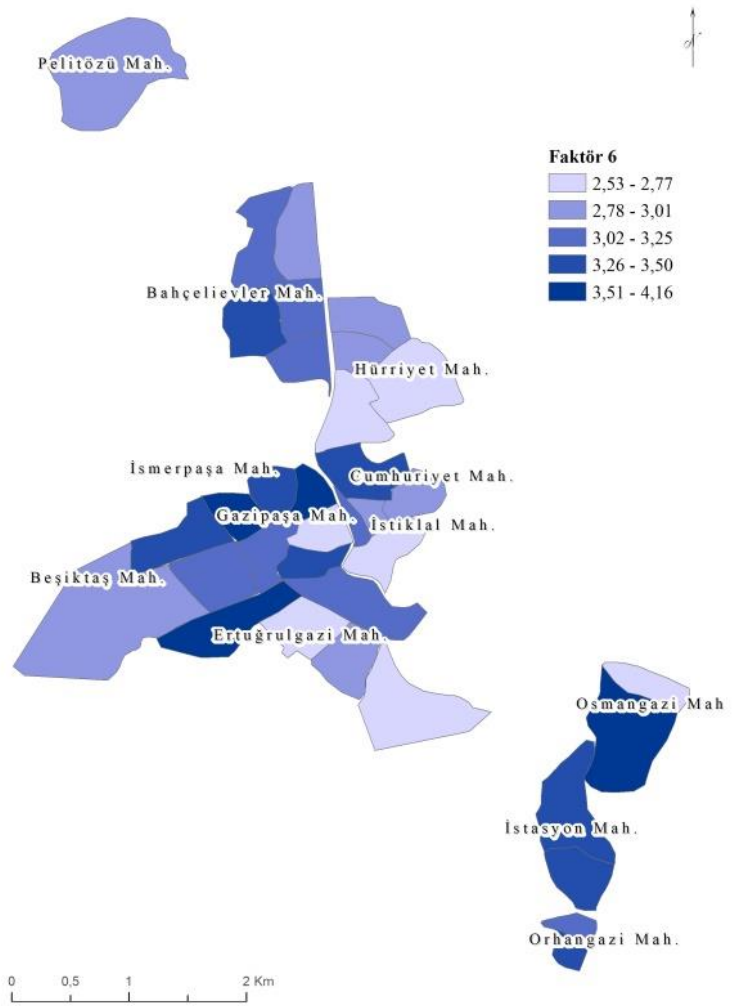

\subsection{Sosyoekonomik Gelişmişliğin Belirleyicileri}

Faktör analizi sonucu elde edilen faktörler ile sosyoekonomik gelişmişlik arasındaki ilişkinin belirlenmesine yönelik basit doğrusal regresyon analizinden faydalanılmıştır. Bağımsız değişkenleri sosyoekonomik gelişmişlik, bağımlı değişkeni ise ilişkisi incelenen faktörler oluşturmaktadır. Sosyoekonomik gelişmişlik değişkeni yüksek, düşük ve orta derecelerinden oluşan sınıflamalı bir değişken olduğu için analize dahil edilmeden önce k-1 kuralından faydalanılarak iki kukla değişken üretilmiştir. Bağımlı kukla değişkenlerin üretilmesinde yüksek sosyoekonomik gelişmişlik düzeyi sabit tutulmuştur.

Kamusal hizmetlerden duyulan memnuniyet bağımlı değişken olarak kabul edilmiştir. Yüksek sosyoekonomik gelişmişlik sabit olmak üzere orta ve düşük sosyoekonomik düzey kukla değişkenlerle ifade edilmiştir. Analiz sonuçları birinci modelde hem orta hem de düşük sosyoekonomik gelişmişlik için anlamlıdır. Katsayılarına 
bakıldığında ise hem orta hem de düşük sosyoekonomik gelişmişlikte kamusal hizmetlerden duyulan memnuniyet oranlarının düşük olduğu görülmektedir. Düşük sosyoekonomik gelişmişlik seviyesinde bu hizmetlerden duyulan memnuniyet orta gelişmişliğe göre daha düşüktür (Tablo 3).

Sosyoekonomik gelişmişlik düzeylerine ilişkin üretilen iki kukla değişken bağımsız değişkenler, sosyoekonomik yaşamdan duyulan memnuniyet ise bağımlı değişken olarak kabul edilmiştir. Analiz sonuçları ikinci modelde hem düşük hem de orta sosyoekonomik gelişmişlik düzeyleri için anlamlıdır. Hem orta hem de düşük sosyoekonomik grubunda yer alan bölgelerde sosyoekonomik yaşamdan duyulan memnuniyet düşüktür. Düşük sosyoekonomik gelişmişlik grubunda yer alanlarda ise sosyoekonomik yaşamdan duyulan memnuniyet orta düzeye göre daha düşüktür (Tablo 3).

Tablo: 3

\section{Regresyon Analizi Sonuçları}

\begin{tabular}{|c|c|c|c|c|c|c|}
\hline \multirow{2}{*}{ Bağımlı Değişken (Faktör) } & & \multicolumn{2}{|c|}{ Standardize Edilmemiș Katsayılar } & \multicolumn{2}{|c|}{ Standardize Edilmiș Katsayılar } & \multirow{2}{*}{ Sig } \\
\hline & & $\mathrm{B}$ & Std. Error & Beta & $\mathrm{t}$ & \\
\hline \multirow{3}{*}{ Kamusal Hizmetlerden Duyulan Memnuniyet } & Constant & 4,086 &, 088 & & 46,313 &, 000 \\
\hline & Dummy_Orta &,- 544 & 105 &,- 646 & $-5,160$ & 000 \\
\hline & Dummy Düșük &,- 995 & 104 & $-1,192$ & $-9,529$ &, 000 \\
\hline \multirow{3}{*}{ Sosyoekonomik Yaşamdan Duyulan Memnuniyet } & Constant & 3,652 & 123 & & 29,591 &, 000 \\
\hline & Dummy_Orta &,- 506 &, 148 &,- 670 & $-3,428$ & 002 \\
\hline & Dummy_Düşük &,- 658 & ,146 &,- 880 & $-4,505$ &, 000 \\
\hline \multirow{3}{*}{ Hane Ekonomisi } & Constant & 3,091 &, 106 & & 29,104 &, 000 \\
\hline & Dummy_Orta &,- 166 &, 127 &,- 315 & $-1,308$ & 200 \\
\hline & Dummy Düşük &,- 193 &, 126 &,- 371 & $-1,539$ & 134 \\
\hline \multirow{3}{*}{ Sosyoekonomik Sermaye } & Constant & 2,167 &, 136 & & 15,876 &, 000 \\
\hline & Dummy_Orta &,- 225 & 163 &,- 331 & $-1,382$ &, 177 \\
\hline & Dummy Düşük &,- 272 & 161 &,- 404 & $-1,686$ & 102 \\
\hline \multirow{3}{*}{ Tehlikeli Madde Kullanımı } & Constant & 4,436 &, 163 & & 27,192 & 000 \\
\hline & Dummy_Orta &,- 084 &, 195 &,- 106 &,- 431 & 670 \\
\hline & Dummy Düşük &,- 182 &, 193 &,- 232 &,- 941 &, 354 \\
\hline \multirow{3}{*}{ Hane Büyüklüğü } & Constant & 3,218 & 149 & & 21,668 & 000 \\
\hline & Dummy_Orta &,- 154 & 178 &,- 214 &,- 869 & 391 \\
\hline & Dummy Düșük &,- 054 & 176 &,- 075 &,- 306 & 962 \\
\hline
\end{tabular}

Araştırma alanında sosyoekonomik gelişmişliğin öznel göstergeler tarafından açıkça denetlendiği görülür. Ulaşım, iletişim ve güvenlik ile ilişkili olarak kavramsallaştırılabilecek kamusal hizmetlerden duyulan memnuniyet sosyoekonomik gelişmişlik konusunda en dikkat çekici faktördür ve çalışma alanında yüksek sosyoekonomik gelişmişliğe sahip olanların aynı zamanda bu hizmetlerden en fazla memnuniyet duyanlardan oluştuğu görülür. Buna karşın kamusal hizmetlerden duyulan memnuniyetin azalması sosyoekonomik gelişmişliğin düşük olması sonucunu doğurur. Gelişmişliğin diğer bir öznel belirleyici ise sosyoekonomik yaşamdan duyulan memnuniyettir. Bu değişken kişisel sağlık ve eğitim, kişi başına düşen gelirden duyulan memnuniyet ve genel mutluluk düzeyi ile karakterize edilir. Sosyoekonomik gelişmişliğin yüksek olduğu bölgelerde ifade edilen unsurlardan duyulan memnuniyet yüksekken gelişmişlik seviyesi düştükçe ilgili değişkenlere ilişkin memnuniyet oranlarının düştügü görülür. Buna göre çalışma alanında sosyoekonomik gelişmişliğin en önemli denetleyicisi gelişmişliğin öznel boyuna ilişkin göstergelerdir. 
Yukarıda ifade edilen faktörler dışındaki dört faktör olan hane ekonomisi, sosyoekonomik sermaye, tehlikeli madde kullanımı ve hane büyüklüğü açısından çalışma alanını oluşturan bölgeler arasında bir farklılık bulunmadığı tespit edilmiştir (Tablo 2).

\section{Sonuç}

Bu çalışmada Bilecik şehrinin sosyoekonomik gelişmişlik profili ve mekânsal karakteristiklerinin belirlenmesi hedeflenmiştir. Bu doğrultuda ekonomik, sosyal ve öznel gelişmişlik boyutlarından oluşan, güvenirliği yüksek özgün bir sosyoekonomik gelişmişlik ölçme aracı geliştirilmiştir. Geliştirilen araçtan faydalanılarak şehrin önceden belirlenmiş 35 bölgesinde ikamet eden bireylerin sosyoekonomik gelişmişlik düzeyleri ölçülmüş ve şehrin sosyoekonomik gelişmişlik haritası oluşturulmuştur. Buna göre şehrin kuzey ve kuzeydoğusunda yer alan bölgelerin sosyoekonomik anlamda daha gelişmiş oldukları belirlenmiştir. Faktör analizi sonuçlarına göre de ölçülen fenomenin altı boyutlu bir yapı olduğu tespit edilmiştir. Bu yapı/faktörlerden ikisinin gelişmişlik üzerinde etkili olduğu belirlenmiştir. Bunlar kamusal hizmetlerden duyulan memnuniyet ile sosyoekonomik yaşamdan duyulan memnuniyettir. Başka bir ifade ile kamusal hizmetlerden ve sosyoekonomik yaşamdan duyulan memnuniyet arttıkça sosyoekonomik gelişmişliğin arttığı gözlenmiş̧ir. Bu anlamda Bilecik şehri örneğinde gerçekleştirilen sosyoekonomik gelişmişlik araştırmasında gelişmişliğin öznel gelişmişlik değişkenleri tarafından denetlendiğini söylemek mümkündür. İlgili yayın dizininde de öznel refaha ilişkin göstergelere yapılan vurgu giderek artmakta olup bu değişkenlerin daha fazla dikkate alınması gerektiğini savunan araştırmacıların sayısı gün geçtikçe artmaktadır (Easterlin, 2006; Kahneman \& Krueger, 2006; International Wellbeing Group, 2006; Camfield \& Esposito, 2014). Bu anlamda araştırmanın öznel refah tarafından denetlenen bir sosyoekonomik gelişmişlik seviyesi burgusu ilgili yayın dizininde savunulan düşünce bağlamında dikkate değerdir. Bu sonuç şehirde gelişmişliği arttırmaya yönelik plan ve uygulamalarda öznel gelişmişliğe ilişkin göstergelerin dikkate alınması gerektiğini göstermektedir.

\section{Kaynaklar}

Ahiler Kalkınma Ajansı (2013), TR71 Bölgesi Illçeleri Sosyoekonomik Gelişmişlik Analizi, <https://ahika.gov.tr/assets/ilgilidosyalar/Tr71-Bolgesi-Ilceleri-SosyoekonomikGelismislik-Analizi.pdf>, 29.03.2019.

Akama, J.S. \& D. Kieti (2007), “Tourism and socio-economic development in developing countries: A case study of Mombasa resort in Kenya", Journal of Sustainable Tourism, 15(6), 735 748.

Akgiş, Ö. \& E. Karakaş (2019), “Coğrafyada Kalkınma Araştırmalarının Kısa Tarihi”, Türk Coğrafya Dergisi, (72), 85-91.

Aktaş, S.G. (2017), “Kapadokya Turizm Bölgesinin Algılanmış İmaj, Memnuniyet ve Sadakat Haritaları: Destinasyon İmaj1, Turist Memnuniyeti ve Turist Sadakatinin Mekânsal Açıdan İncelenmesi”, Proje No: 1506E478, Anadolu Üniversitesi, Eskişehir.

Alderete, M.V. (2017), "Examining the ICT access effect on socioeconomic development: The moderating role of ICT use and skills", Information Technology for Development, 23(1), $42-58$. 
Anderson, T. \& H. Kohler (2015), "Low fertility, socioeconomic development, and gender equity", Population and Development Review, 41(3), 381-407.

Camfield, L. \& L. Esposito (2014), "A Cross-Country Analysis of Perceived Economic Status and Life Satisfaction in High-And Low-Income Countries", World Development, 59, 212 223.

Cheng, X. \& L. Chen \& R. Sun \& P. Kong (2018), "Land use changes and socio-economic development strongly deteriorate river ecosystem health in one of the largest basins in China", Science of The Total Environment, 616-617, 376-385.

Conceição, P. \& R. Bandura (2008), "Measuring Subjective Wellbeing: A Summary Review of The Literature", United Nations Development Programme (UNDP) Development Studies, Working Paper.

Çubukçu, K.M. (2015), Planlamada ve Coğrafyada Temel İstatistik ve Mekânsal İstatistik, Ankara: Nobel Akademik Yayıncılık.

De Jong, A. \& P. Varley (2017), "Food tourism policy: Deconstructing boundaries of taste and class", Tourism Management, 60, 212-222.

Dinçer, B. \& M. Özaslan (2004), İlçelerin Sosyoekonomik Gelişmişlik Sıralaması Araştırması, DPT, Bölgesel Gelişme ve Yapısal Uyum Genel Müdürlüğ̈, Ankara.

Doğu Anadolu Kalkınma Ajansı (2013), TRB2 Bölgesinde Bulunan İlçelerin Sosyoekonomik Gelişmişlik Stralaması, <http://www.daka.org.tr/panel/files/files/arsiv/Ara\%C5\%9Ft\%C4\%B1rmalar\%20ve\%20 Analizler/TRB2\%20B\%C3\%B6lgesi\%20il\%C3\%A7eleri\%20Sosyoekonomik.pdf>, 29.03.2019.

Dowling, R. \& D. Newsome (2018), Handbook of Geotourism, Edward Elgar Publishing.

Easterlin, R.A. (2006), "Life Cycle Happiness and Its Sources: Intersections of Psychology, Economics, and Demography", Journal of Economic Psychology, 27(4), 463-482.

Farsani, N.T. \& C. Coelho \& C. Costa (2011), "Geotourism and geoparks as novel strategies for socio-economic development in rural areas", International Journal of Tourism Research, 13(1), 68-81.

Field, A. (2000), Discovering Statistics Using SPSS For Windows, London: Sage.

Fujii, T. (2008), "How Well Can We Target Aid With Rapidly Collected Data? Empirical Results for Poverty Mapping from Cambodia”, World Development, 36(10), 1830-1842.

Fuseini, I. \& J. Kemp (2015), “A review of spatial planning in Ghana's socio-economic development trajectory: A sustainable development perspective", Land Use Policy, 47, 309-320.

Gerner, D. \& P. Rybár \& J. Engel \& L. Domaracká (2009), “Geotourism marketing in Lake Constance’ region”, Acta Montanistica Slovaca, 14(2), 197-204.

Getis, A. \& J.K. Ord (1992), “The Analysis of Spatial Association By Use of Distance Statistics”, Geographical Analyses, 24(3), 189-206.

Henninger, N. \& M. Snel (2002), Where are the Poor? Experiences with the Development and Use of Poverty Maps, World Resources Institute, Washington D.C.: Arendal.

Huebener, M. \& D. Kuehnle \& C.K. Spiess (2019), "Parental leave policies and socio-economic gaps in child development: Evidence from a substantial benefit reform using administrative data", Labour Economics, 61, 101754.

Hyman, G. \& C. Larrea \& A. Farrow (2005), "Methods Results and Policy Implications of Poverty and Food Security Mapping Assessments", Food Policy, 30(5), 453-460. 
International Wellbeing Group (2006), Personal Wellbeing Index, 4th Edition, Melbourne, Australian Centre on Quality of Life, Deakin University.

İlhan, Ö.A. \& E. Karakaş \& B. Özkaraman (2020), “'Cittaslow’: An Alternative Model for Local Sustainable Development or Just a Myth? Empirical Evidence in the Case of Tarakli (Turkey)", Quaestiones Geographicae, 39(4), 23-37.

Kahneman, D. \& A.B. Krueger (2006), "Developments in The Measurement of Subjective WellBeing", The Journal Of Economic Perspectives, 20(1), 3-24.

Karakoç, F.Y. \& L. Dönmez (2014), “Ölçek Geliştirme Çalışmalarında Temel İlkeler”, Tıp Eğitimi Dünyası, 40, 39-49.

Lambin, E.F. \& P. Meyfroidt (2010), "Land use transitions: Socio-ecological feedback versus socioeconomic change", Land Use Policy, 27(2), 108-118.

Long, H. \& G.K. Heilig \& X. Li \& M. Zhang (2007), "Socio-economic development and land-use change: Analysis of rural housing land transition in the transect of the Yangtse river, China", Land Use Policy, 24(1), 141-153.

Ma, S. \& A.P. Kirilenko \& S. Stepchenkova (2020), "Special interest tourism is not so special after all: Big data evidence from the 2017 great American solar eclipse", Tourism Management, 77, 104021.

MacKinnon, D. \& A. Cumbers (2007), An Introduction To Economic Geography: Globalization, Uneven Development and Place, Pearson Education.

Orta Karadeniz Kalkınma Ajansı (2014), TR83 Bölgesi İlçeleri Sosyoekonomik Gelişmişlik Endeksi, <http://www.oka.org.tr/Documents/TR83\%20ILCE\%20SEGE.pdf>, 29.03.2019.

Özdamar, K. (2016), Ĕgitim, Sağlık ve Davranış Bilimlerinde Ölçek ve Test Geliştirme Yapısal Eşitlik Modellemesi, Nisan Kitabevi, Eskişehir.

Palvia, P. \& N. Baqir \& H. Nemati (2018), "ICT for socio-economic development: A citizens' perspective", Information \& Management, 55(2), 160-176.

Peet, R. \& E. Hartwick (2009), Theories of Development: Contentions, Arguments, Alternatives, Guilford Publications.

Pernecky, T. \& C. Johnston (2006), "Voyage through numinous space: Applying the specialization concept to new age tourism", Tourism Recreation Research, 31(1), 37-46.

Potter, R.B. \& T. Binns \& J.A. Elliott \& D. Smith (2004), Geographies of Development, 2nd Edition, Harlow: Pearson.

Rogers, T. (2008), Conferences and conventions: A global industry, 2nd Edition, Elsevier Ltd, Burlington, MA.

Roztocki, N. \& H.R. Weistroffer (2016), “Conceptualizing and researching the adoption of ICT and the impact on socioeconomic development", Information Technology for Development, 22(4), 541-549.

Schmitz, M. \& D. Matos \& I. De Aranzabal \& D. Ruiz-Labourdette \& F. Pineda (2012), "Effects of a protected area on land-use dynamics and socioeconomic development of local populations", Biological Conservation, 149(1), 122-135.

Sen, A. (1987), The Standard of Living, Cambridge University Press, New York.

Shi, K. \& L. Wu (2020), "Forecasting air quality considering the socio-economic development in Xingtai”, Sustainable Cities and Society, 61, 102337.

Thoma, M.V. \& F. Bernays \& C.M. Eising \& V. Pfluger \& S.L. Rohner (2020), "Health, stress, and well-being in Swiss adult survivors of child welfare practices and child labor: 
Investigating the mediating role of socio-economic factors", Child Abuse \& Neglect, 104769.

Tian, Y. \& L. Wang (2019), "Mutualism of intra- and inter-prefecture level cities and its effects on regional socio-economic development: A case study of Hubei province, central China", Sustainable Cities and Society, 44, 16-26.

Todaro, M.P. \& S.C. Smith (2006), Economic Development, Harlow.

Tong, H. \& J. Kang (2020), "Relationships between noise complaints and socio-economic factors in England", Sustainable Cities and Society, 102573.

Wang, L. \& H. Yan \& X. Wang \& Z. Wang \& S. Yu \& T. Wang \& Z. Shi (2020), “The potential for soil erosion control associated with socio-economic development in the hilly red soil region, southern China", CATENA, 194, 104678.

Wu, K. \& X. Ye \& Z. Qi \& H. Zhang (2013), "Impacts of land use/land cover change and socioeconomic development on regional ecosystem services: The case of fast-growing Hangzhou metropolitan area, China", Cities, 31, 276-284.

Yüncü, D. \& S.G. Aktas \& Y.M. Kantar (2018), "The relationship between destination image, satisfaction and loyalty in the context of cultural heritage site [online]", in: Y. Tamara \& P. Stolk \& G. McGinnis (eds.), CAUTHE 2018: Get Smart: Paradoxes and Possibilities in Tourism, Hospitality and Events Education and Research, Newcastle, NSW:

Newcastle Business School, The University of Newcastle, 891-896.

Zhang, C. \& L. Luo \& W. Xu \& V. Ledwith (2008), “Use of local Moran's I and GIS to identify pollution hotspots of $\mathrm{Pb}$ in urban soils of Galway, Ireland", Science of The Total Environment, 398(1-3), 212-221. 
Akgiş-İlhan, Ö. \& E. Karakaş (2021), "Bilecik Şehrinin Sosyoekonomik Gelișmișlik Profilinin Mekânsal Analizi”, Sosyoekonomi, 29(48), 205-227. 